Електронне наукове фахове видання "Ефективна економіка" включено до переліку наукових фахових видань України з питань економіки

(Категорія «Б», Наказ Міністерства освіти і науки України від 11.07.2019 № 975) www. economy.nayka.com.ua | № 8, 2020|27.08.2020 p.

DOI: $\underline{10.32702 / 2307-2105-2020.8 .1}$

УДК 336.276

Yu. Safonov

Doctor of Economic Sciences, Professor,

Kyiv National Economic University named after Vadym Hetman

ORCID ID: 0000-0001-5623-1965

H. Hryhoriev

Doctor of Economic Sciences, Associate professor,

National University of "Kyiv - Mohyla Academy"

ORCID ID: 0000-0003-2349-3875

\title{
IS SOVEREIGN DEBT RESISTANCE OVERCOMING A PREMISE OF SOVEREIGN DEFAULT PATH DEPENDENCE OCCURENCE?
}

\author{
Ю. М. Сафонов, \\ д. е. н., професор, \\ ДВНЗ «Київський начіональний економічний університет імені Вадима Гетьмана» \\ Г. С. Григор'єв, \\ д. е. н., доцент, Національний Університет «Києво - Могилянська академія»

\section{ЧИ Є ПРОТИДІЯ ПОДОЛАННЮ СУВЕРЕННОГО БОРГУ ПЕРЕДУМОВОЮ ВИНИКНЕННЯ ЗАЛЕЖНОСТІ ПОПЕРЕДНЬОГО РОЗВИТКУ СУВЕРЕННОГО ДЕФОЛТУ?}

The main aim of the article is to analyze the interconnection between sovereign debt resilience and sovereign default path dependence with its application for Ukrainian economy. There were system dynamics methods used in this research with the simulation using Polya process probability (Polya urn). We used the statistical data base of the Ukrainian economy and fundamental works in system dynamics and sovereign debt analysis.

We examine in the article the problem of overcoming existing sovereign debt mental model resilience to external and internal shocks in a situation of uncertainty and the issue of the appropriate instruments for sovereign debt resilience conceptual analysis application. The causal loops diagrams are used to demonstrate the main effects arising under the policy dilemma conducting of sovereign debt default or its repayment.

Among the main consequences of not overcoming the existing mental model is 1) the obsolete sovereign debt management financial structure of the society management method (The Deming cycle is used according to the scheme: "Plan - work - check - activity", or "Plan - execution - check - adjustment" to explain the existing principle of sovereign debt service.) 2) foreign direct investment decreasing versus external debt decreasing, which slows down the process of economic development 3) The disproportion between national savings and investment 4) The absence of the resistance in sovereign debt policy mechanism. The author highlights, that under Pola process the system does not lock in to possible balance - we are not observing the uniform distribution of the proportion of sovereign defaults. Positive feedback loops are overlapped by undetermined negative one. 
Polya process in a case of the sovereign default versus debt repayment with the appropriate density function for sovereign default probability after 29 years (trials) has been used to demonstrate the nonlinearity processes of the appropriate policy choice. The main conclusion is that the equilibrium distribution of the Polya process is not quite uniform. We are observing a locally unstable disequilibrium with the positive feedback but impossibility to lock in in a certain point.

Основна мета статті - проаналізувати взаємозв'язок між стійкістю суверенного боргу та залежністю від дефолту суверенного капіталу з його застосуванням для економіки України. У иьому дослідженні були використані методи системної динаміки при моделюванні $з$ використанням ймовірності (урни) Пойі (Polya process). Використано статистичну базу даних економіки України та фундаментальні роботи в системній динаміці та аналізі суверенного боргу.

У статті розглянуто проблему подолання існуючої ментальної моделі стійкості суверенного боргу до зовнішніх та внутрішніх потрясінь в умовах невизначеності та проблему використання відповідних інструментів конщептуального аналізу стійкості боргу. Діаграми причинно-наслідкових циклів використовуються для демонстрачії основних наслідків, щзо виникають під час вирімення дилеми проведення політики дефолту суверенного боргу чи його погашення.

Серед основних наслідків відсутності подолання існуючої ментальної моделі є 1) застаріла суверенна фінансова структура управління боргом методом управління суспільством (Використано иикл Демінга за схемою: "План - робота - перевірка - діяльність, або «План виконання - перевірка - коригування» для пояснення наявного принципу обслуговування суверенного боргу) 2) зменшення прямих іноземних інвестицій порівняно із зменшенням зовнішнього боргу, щзо уповільнюе процес економічного розвитку 3) диспропориія між національними заощадженнями та інвестиціями 4) відсутність механізму опору в політиці суверенного боргу. Автор підкреслює, що в процесі Пойі система не фіксується на рівноважному рівні - ми не спостерігаємо рівномірного розподілу частки суверенних дефолтів. Позитивні петлі зворотного зв'язку перекриваються недетермінованими негативними.

Було використано процес Пойі у випадку девальващії суверенних держав проти погашення боргу з відповідною функцією густини для вірогідності дефолту суверенних держав після 29 років (випробування) для демонстрачії нелінійних прочесів вибору відповідної політики. Основний висновок полягає в тому, щзо рівноважний розподіл процесу Пойі не зовсім рівномірний. Ми спостерігаємо локально нестабільну нерівновагу з позитивним зворотним зв'язком, але неможливістю фіксації у певній точизі.

Key words: sovereign debt servicing mental model; sovereign debt repayment; sovereign debt default; sovereign debt resilience; financial vulnerability; foreign direct investment; gross domestic savings; Deming cyle; Polya process; sovereign default path dependence.

Ключові слова: ментальна модель обслуговування суверенного боргу; повернення суверенного боргу; дефолт суверенного боргу; стійкість суверенного боргу; фінансова вразливість; прямі закордонні інвестииї; валові внутрішні заощадження; иикл Демінга; проиес Пойі; залежність попереднього розвитку суверенного дефолту.

Formulation of the problem in generally and related issues, which are important in scientific and practical tasks

Modern global economy is overburden with unpaid external debts. The global economy is entering the period of economic instability and dynamic complexity which may ruin the developing countries at first (including Ukraine). The ability to overcome mental crisis on the level of social system and return to pre - crisis status after long - run debt dependence is the one of the most important components of the macroeconomic system, which means reaching the new social mental boundaries. To reproduce the behaviour of the debt system, primarily the sovereign debt system, we need to develop special instruments for explaining its structure. 
Modern world economy is deeply stuck in debt and is confronting with the world recession explosion. The sovereign debt is a problem not just from economic but as well from mental point of view, which has deep historical and cultural roots. The indirect sovereign debt effect will deepen the existed financial and economic crisis. The short run direct and side effects of sovereign debt are unavoidable due to static mental behavioural effects driven by economic long - run effects misperceptions. The sovereign default, which by fact has happened in Ukraine in 1995 and 2005 may be considered as a cyclical process with the possibility of sovereign default iteration in the future.

The erroneous perception of the macroeconomic situation creates erroneous debt policy as a result of speeding up the structural changes in the society due to cyclical macroeconomic shocks and necessity of production technological upgrade. Learning as a system process in macroeconomics, beginning from Keynesian revolution, creates new forms of economy stimulation and simultaneously creates the possible side effect of chronic budget deficit, which is needed to be compensated. Due to the inefficient macroeconomic policy, debt resilience may be weak or fail, which worsens the situation. The general sum of external debt payment induces the developing countries to redistribute the export revenue from investing into new technological sectors to sovereign debt compensation which determines the relevance of the research.

Sovereign debt resilience conceptual models and specific simulation methods are developed for better understanding of sovereign debt as a systemic problem. The main recommendations are needed to be given to Ministry of Finance of Ukraine, as the main responsible institutions for external borrowing as well as suppliers of it (international financial organizations, private financial institutions - etc.). The research is based on system dynamics methodology.

The mental memory of the society does not allow to overcome the sovereign debt crisis and sovereign debt path dependence - the situation repeats constantly. The relevance of the research is determined by the inevitability of the sovereign default and attempts to avoid it. After changing the structure of the economic system, we can change the type of the national economic behaviour and avoid sovereign default. To avoid the sovereign debt trap, we need to take into account "rational behaviour" as well as "irrational one". The combination of the above-mentioned factors leads to the advancement in sovereign debt mental perception and increasing the national welfare in the long - run by decreasing the external sovereign debt. Small steps, directed to the policy goal achievement, eventually lead to the new structure of the system. The international financial institutions can also change their attitude towards sovereign risk.

Sovereign debt policy rescheduling includes the aspects of human behaviour for making human decisions in macroeconomic policy, which are based on existed collective mental models. The "actual" mental thinking and decision making of the nation (in the context of sovereign debt policy) is badly explored in science. The strategic task of mental model redesigning is to expand the "cognitive capacity" of the society for sovereign debt problem solving.

The common strategy of the society in sovereign debt resolution creates the $3^{\text {rd }}$ level of redesigning the reality - mental long - run strategy. The core issue of sovereign debt indebtedness is the saving - investment equilibrium. The lack of ability to increase the saving rate of return leads to external inflow of borrowing increasing. Automatic thinking forms our perception of reality. The neoclassical concept takes into consideration mental accounting and neglects social and mental thinking. Sone efforts is needed to rebuild our thinking. There is a pattern of thinking which is quite difficult to come out. "The mind, society and behaviour framework points to new tools for achieving development objectives" $[18, \mathrm{p} .4]$

According to [7], "the history of sovereign debt evolved over time along with the purposes for which governments borrowed: first state building, then public-good provision, and most recently social welfare and entitlements". The evolution of sovereign debt has led to gradual or fast change in economic and financial structure of the society, depending on the policy resistance to macroeconomic policy. "Historically there has been strong official resistance to central banks selling bonds when governments have heavy debts to refinance ... particularly when longterm rates are already rising" [4, p.25].

"Negotiation of sovereign debt is a complex endeavor. Its complexity results both from structural characteristics - number of actors, problems of coordination, communication, cooperation and conflict and from cognitive limitations" [12]

The complexity of sovereign debt problem requires comprehensive mental adjustment in macrosystems in a way of systems thinking to achieve the high level of sovereign debt system resilience and to avoid the resistance of separate economic agents to changes.

Analysis of the recent studies and publications that have initiated the solution of this problem, definition of the unresearched part of the paper's general problem.

Sovereign debt problem in a context of the system dynamics concept of path dependence has not been studied well. Among the national researches we can admit Grabchuck O. [8], Smirnov O.[14] and others. Among many foreign scientific studies in the field of sovereign debt servicing and system dynamics it may be noted Kahneman D. [9], Sterman J.[16], Eichengreen B.[7], Blommestein, H.[4] and others.

\section{The formulation of the paper's objective}

The aim of the article is: to create the appropriate instruments for sovereign debt resilience conceptual analysis with the system of indicators; exploring the current state of sovereign debt in Ukraine; simulation modelling for testing and improving the existing sovereign debt mental model resilience to external and internal shocks; recommendations for sovereign debt management in the context of debt resilience and path dependence. The resilience to external debt shocks is one of the basic structures for path dependence analysis.

Presentation of the basic material of the study with justification of the obtained scientific results.

The attempts to improve the situation with the sovereign debt resilience may made things worse. The unbalanced approach to sovereign debt in Ukraine in the period of $1992-2000$ provoked the resistance of the 
macrosystem to itself and technical default in 2000, which assumes the possibility of sovereign default path dependence (small random events [16, p.349] creates larger perturbations in the future).

Consider as an example of financial vulnerability unexpected dynamics as a case of policy resistance in Ukraine. To calculate financial vulnerability, we use the methodology of [10] Sovereign debt defaults and financing needs] which is calculated as:

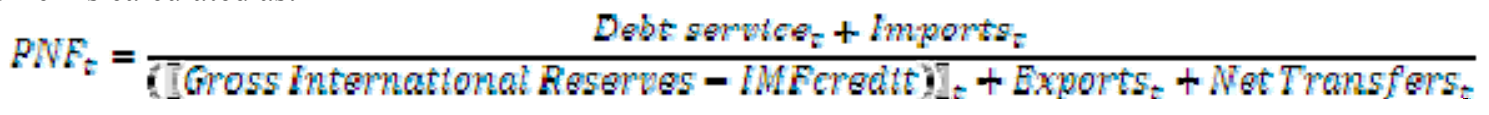

where PNF stands for proportion of new financing needs and shows the proportion by which current uses of foreign income exceed current foreign

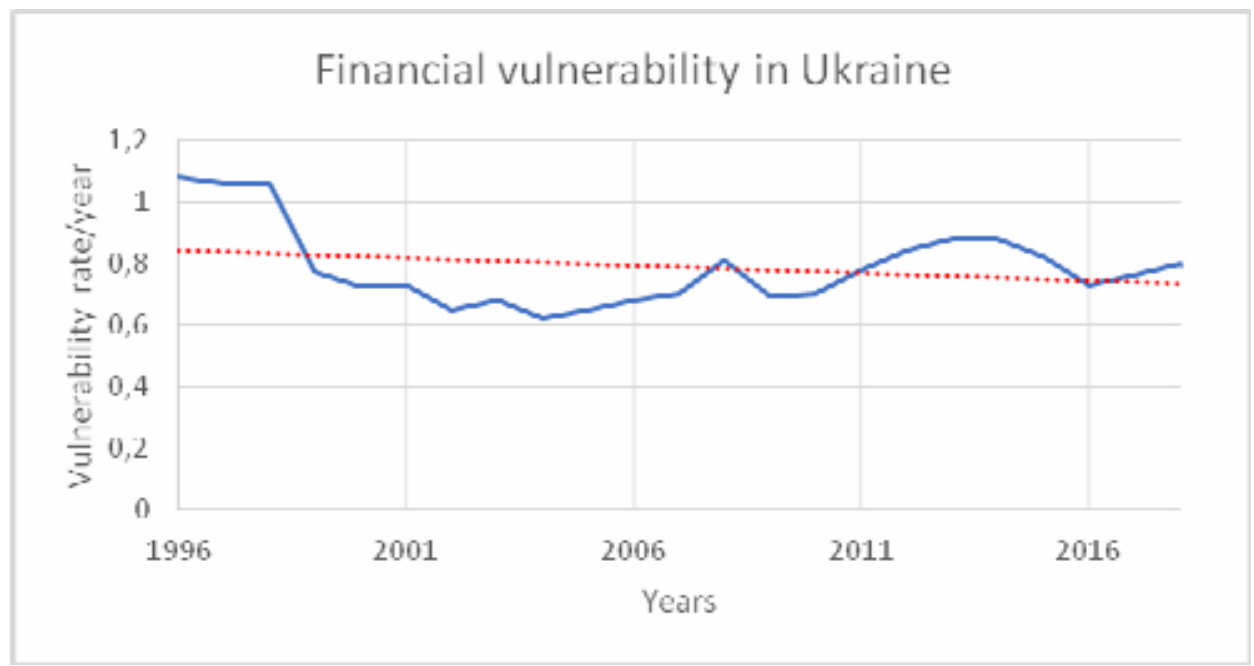

Fig. 1. Financial vulnerability in Ukraine

The financial vulnerability was falling up to the period of Global Financial Crisis which are to be considered as a positive signal. The national debt containment policy till 2008 was quite successful but failed later - the PNF dropped to the average of 0.8 and there is no guarantee of achieving the level of 1 after increasing of debt repayment after 2020.

Why the financial vulnerability in Ukraine is increasing at least since 2010? (the blue bold line is situated over red dotted line on Fig.1). The possible answer is in the dimension of relationships between Sovereign Debt (SD) and Foreign Direct Investment (FDI) as the alternative forms of national economy external financing. The substantial overcoming or even approaching to equal sum of SD to FDI leads to financial vulnerability increasing. The reason for this is in productive nature of FDI versus unproductive (speculative) nature of external financial borrowings (especially IMF credits). Despite the fact of repatriation of the main part of the profit to donor country, FDI plays the role of the engine in economic growth contrary to the borrowings of some of the global financial institutions. The following Figure 2 justifies the above-mentioned assumptions.

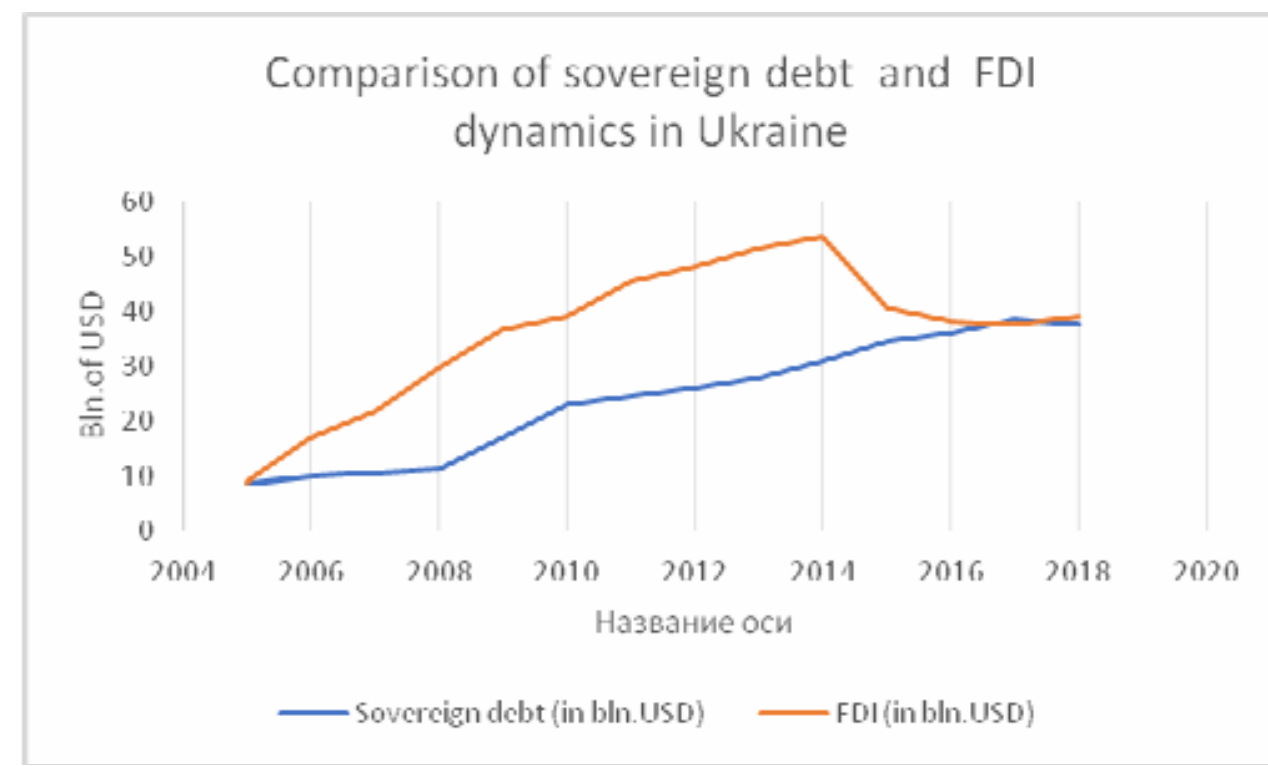

Fig. 2. Comparison of sovereign debt and FDI dynamics in Ukraine 
The unanticipated reaction (resistance) of the global credit system is reflected in alternative ways of external debt pressure on national economy because of it growth in geometrical progression. We expect an exponential debt growth in Ukraine after 2021. The weakening debt pressure is compensated by selling the national assets, the latest of it is land resources. The worsening demographic situation in Ukraine is a side effect of inappropriate sovereign debt policy.

To understand the policy resistance, we need to explore the side - effects, which are arising as the result of sovereign debt inappropriate policy (indicated in worsening financial vulnerability indicator): "the main consequences of a growing national debt are:

- $\quad$ Lower national savings and income;

- $\quad$ Higher interest payments, leading to large tax hikes and spending cuts;

- $\quad$ Decreased ability to respond to problems;

- Greater risk of a fiscal crisis" [5]

Fighting against sovereign debt was the most active in the period of $2001-2007$ - the ratio of sovereign debt/GDP decreased substantially. Intervening on the sovereign debt market has finished unsuccessfully and the economy returned to some natural rate of indebtedness level, calculated by proportion of new financing needs. The ratio of sovereign debt /GDP indicates the same trend and has the inverse relationship with the gross domestic savings.

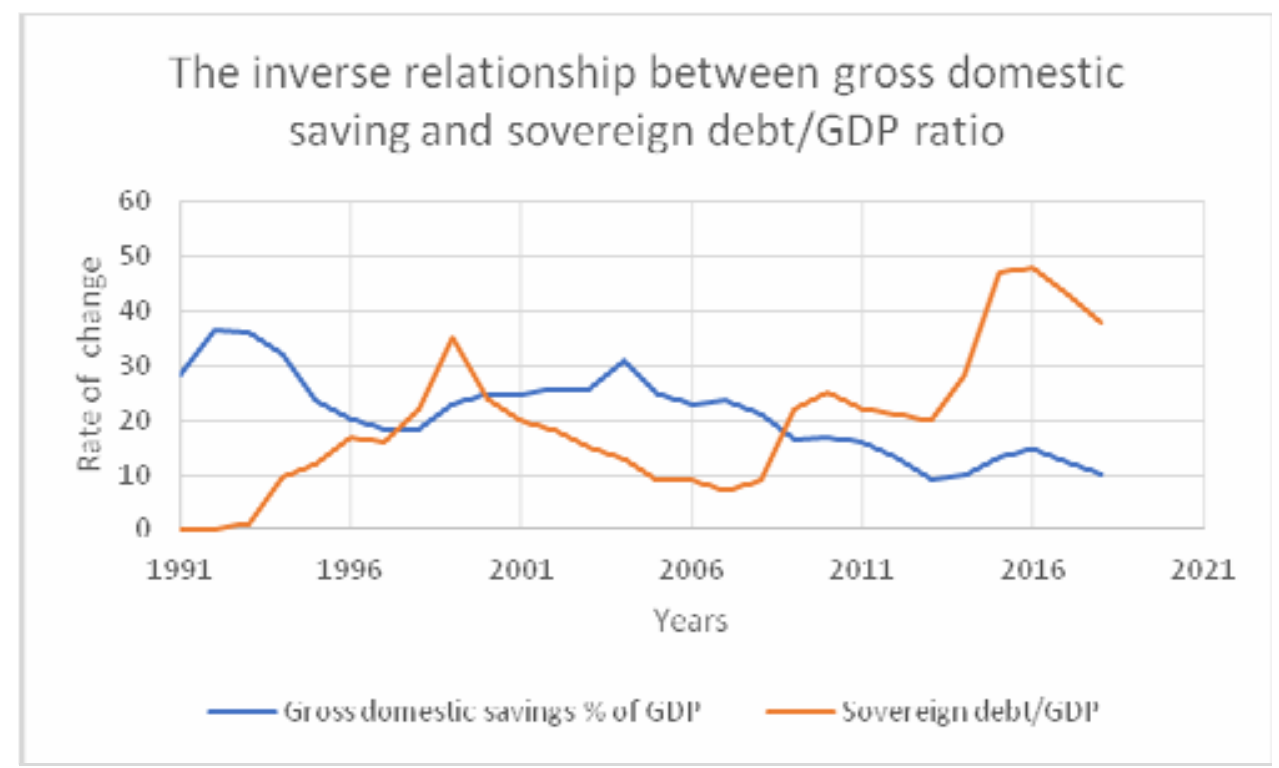

Fig. 3. Sovereign debt /GDP ratio and gross domestic savings in Ukraine

The figure 3 reflects the fact, that during the period of sovereign debt fighting in $2001-2007$ the positive side effect of domestic savings increasing was not taken into account to the full extent. The level of gross domestic savings has started to fall long before the beginning of global financial crisis and harmed the positive signals of sovereign debt decreasing and economy recovering. Macroeconomic policy of Ukraine was not directed on stimulation of private investment and investment.

To discover the sovereign policy resistance mechanism in a context of gross domestic savings, we use feedback concept with the parameters of $[14, \mathrm{p} .15]$. 


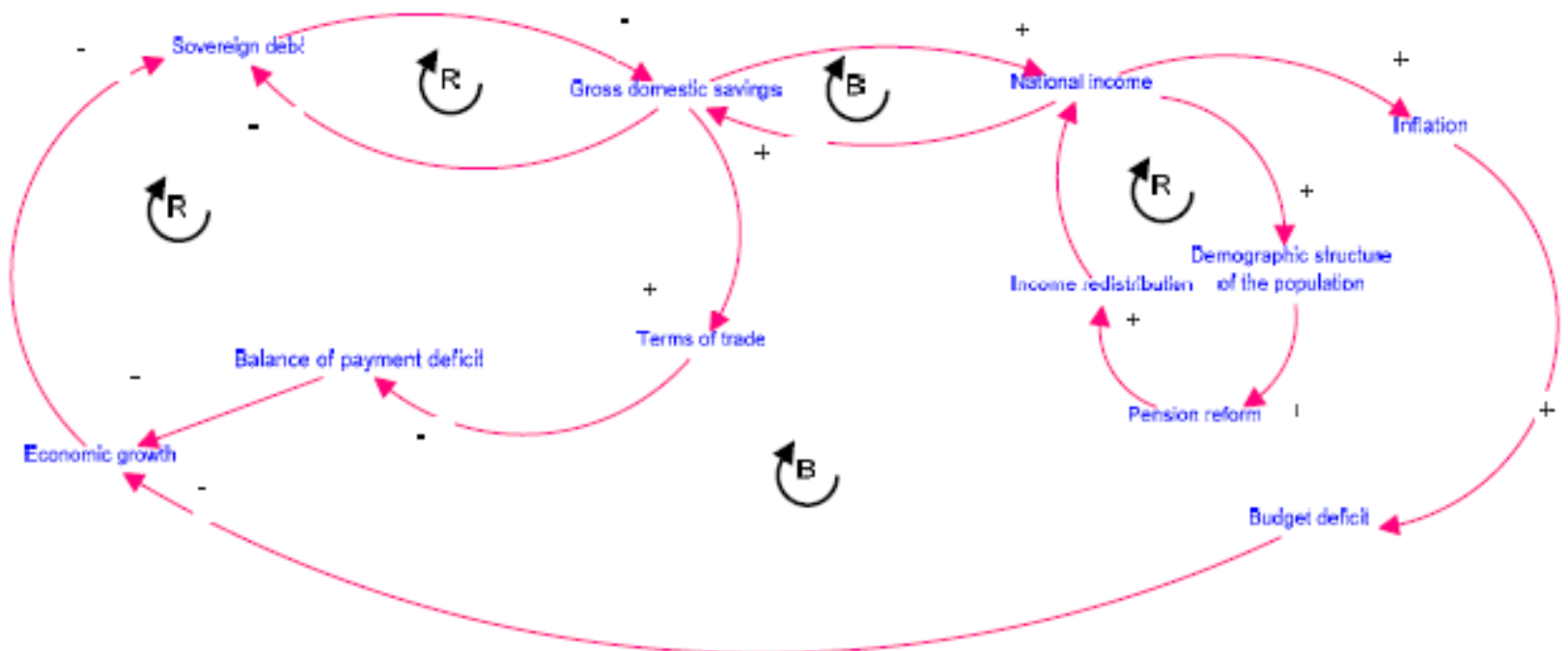

Fig. 4. The basic sovereign debt dynamics with gross domestic savings as initial point

Learning depends on feedback, described above. [16, p.15]. We use PDCA (plan-do-check-act or plan-docheck-adjust) management method, also called the Deming circle, to explore the possible scenario of changing the mental model of the society debt perception for further changing of the behaviour via the structure of the system. To build the real closed feedback system we use the information from [1]. The sovereign debt PDCA model on Fig. 5 reflects the basic idea of system dynamics main closed circle, but doesn't reflect the criteria of mental model formation. Ukraine is fighting to lower and control the level of debt with the potential side effects, among which is economic recession, consumer confidence falling and inflation which worsens macroeconomic situation in general. The harmful effect of sovereign debt repayment is predetermined. Sovereign debt is severe issue which needs the adequate policy instruments to be implemented. The system behaviour is in a mental trap of erroneous sovereign debt policy which has the tendency of iteration again and again. This may happen in Ukraine again after global financial crisis in 2008 and financial turbulence in 2014. The coronavirus effect and other current economic issues can distract the society from inevitable turmoil and economic collapse, which the repudiation to pay in a future may cause. The core idea of the article is to change the sovereign debt mental behaviour of the nation in general, namely we need to take into account psychological, historical, cultural and other factors, which are laying beyond "homo economicus" rational choice decisions. Making macroeconomic choice leads to new decisions with new positive and negative side effects on economic growth and wellbeing increasing. The relatively small macroeconomic policy corrections can lead to large economic shifts. Not only the fact of implementation, but the way of implementation is important.

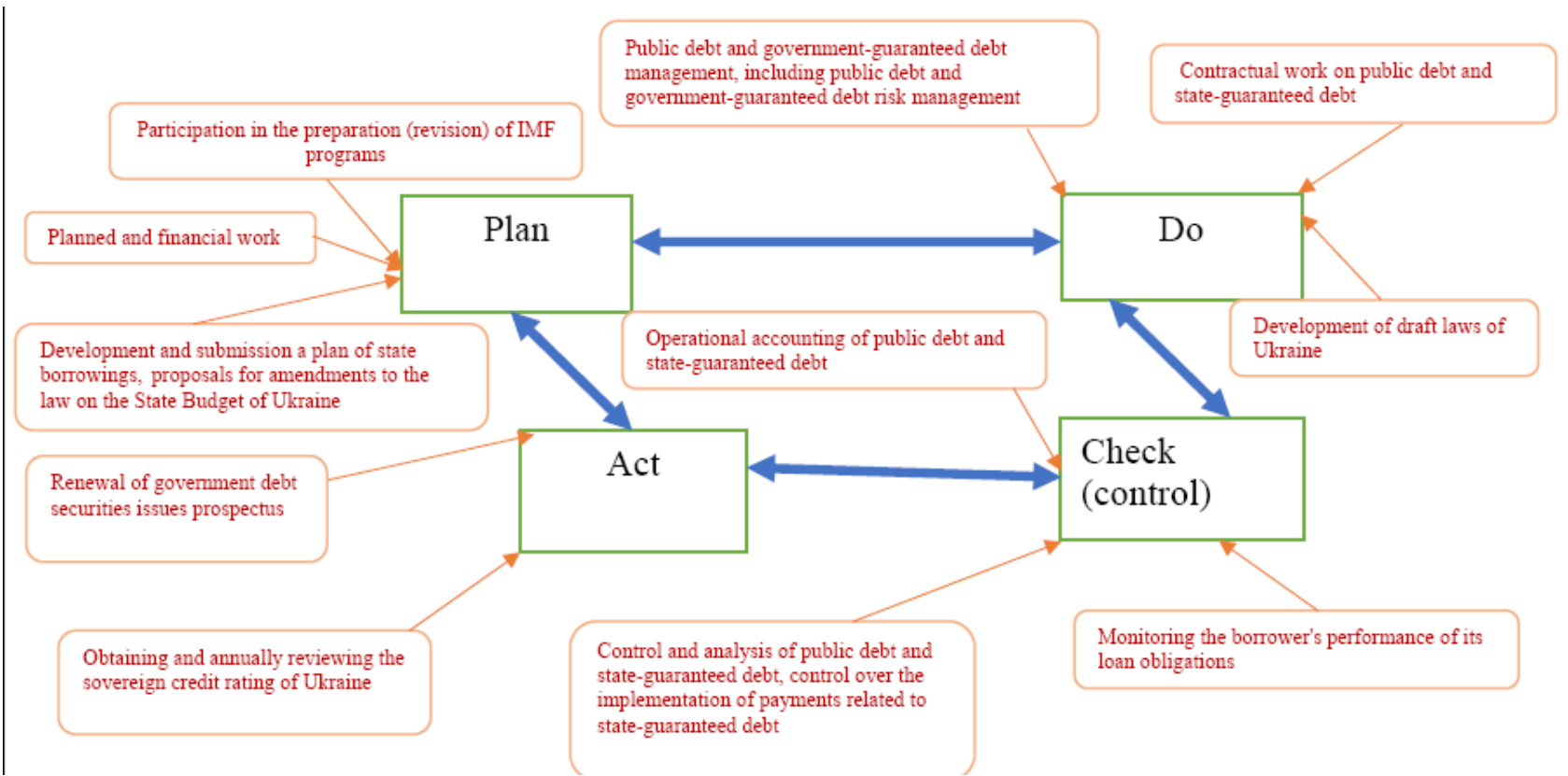

Fig. 5. The sovereign debt PDCA model 
The dynamic model option of Figure 5 needs to be created with the instruments of redesigning of collective sovereign debt behaviour with irrational decisions. There are at least 3 set of methodological concepts to describe development policy [18] with its possible implementation to sovereign debt policy:

- $\quad$ "Thinking automatically", or mental accounting;

- "Thinking socially";

- $\quad$ "Thinking with mental models"

Mental accounting is well - described concept on micro - level, which needs to be implemented on macrolevel. The society (primarily developing countries) in general evaluates the losses from sovereign debt repayment lower than possible benefits from effective external credits allocations. The associative "automatic" thinking has led to the global financialization and economic distortions in developing countries, including Ukraine. The investments in education, infrastructure and innovations for creation of procyclical economic growth are ineffective or absent. Learning from others (deliberate thought, as it described in [9]) with the associative "automatic" thinking combination is the way out of sovereign debt mental accounting debt trap. Most official borrowers in developing countries are automatically thinking about absence of financial dependence and unfair financial exchange. In reality "international investments do not serve as a catalyst for the country's economic growth, because profits return to the centre" [2].

"Collective patterns of behaviour" are forming our social aggregate view on sovereign debt problem. To think socially we need to develop a system of above mentioned tools for state regulation of financial and economic processes, which is formed on the basis of systematic and semantic approaches to the influence of state institutions on segments of the national economy for use in the process of forming strategic guidelines and citizen public debt audit, which will allow effective state regulation of national economy and its components. Thinking socially leads to changing of our aggregated believes (mental model) about the nature and way out from sovereign debt. Predicting possible scenarios of economic development and creating appropriate feedback loops will improve the situation with sovereign debt policy implementation.

The existed scientific literature on sovereign debt is not primarily based on estimation of psychological and social factors of policy decision. Sovereign debt problem is enormously social problem. Macroeconomic multidisciplinary perspective of behavioural economics may serve as a methodological basis for further research. To think socially in terms of sovereign debt we need to admit the humans being not only with "animal spirit" but also with "social spirit", the combination of which gives us the mental model.

According to system dynamics mental modelling the national economy of developing economy can play an active (not passive role) in transforming its role in global economic space due to mental modelling change. "It is responsible for [its own] destiny and should strive to be an originator rather than a pawn, active rather than passive, responsible rather than helpless" [3, p. XI of Introduction]

Enthalpy is an order of the system as an alternative to entropy. "External public debt is a significant factor in the uncertainty of Ukraine's economic development. The dynamics of entropies of structurally organized elements of external debt testifies to the endogenous nature of the crisis in this sector of the economy" [8,p.66]. Nevertheless, primary fluctuations in a form of primary sovereign debt are needed for the evolution of the system and their complication in the system. It also depends from the position of the sovereign debt evaluator: if it the highest level (global financial system) - the system is ordered but if it is the lowest level (national financial systems and its elements) - the system looks disordered, which also determines the level of our double - loop learning. The level of our financial competence determines the ability to change national mental model. On the other hand, national financial system, using the number of fluctuations choose the way of further development. The chance of positive fluctuation gives an opportunity to quit from debt trap. One of this chance have being lost in Ukraine approximately in the period of $2003-$ 2007 economic stabilization. The bifurcation has appeared with unpredictable (for national mental level) results of Orange revolution and global financial crisis in 2008 - 2009.

Ukrainian financial system, including sovereign debt is a part of global financial system (not a closed system by itself) and always has a risk to be in a disequilibrium state. The opportunity to develop independent national system of developing country arises on the edge of enthalpy and entropy. To evaluate the level of the greater system fluctuation we need to be a greater financial player on the global level with a greater potential to change mental model. This implies learning and transformation of external and internal economic environment for creating alternative behaviour. The impossibility to create alternative behaviour eliminates the possibility for double - loop learning. We need to establish the system of dynamic complexity evaluation in sovereign debt analysis [16, p. 22]. The dynamic characteristics of Ukrainian sovereign debt may be explained by at least eight different stages of Ukrainian national debt formation [15, p.25]. Each of this stage has absolutely different structure form from the previous one: there was a moderate level of external debt increasing till 2008 and "growing of financial crisis and increasing debt burden" [15, p.25]. One of the reasons, why the dissimilarity of sovereign debt with its different stages happened can be explained by tightly coupled components of the system analysis [16, p. 22]. "In the classical work [6] there are three agents in a sovereign debt environment: a single government, international lenders and a bail - out agency" [13]. We propose to extend the boundaries of the sovereign debt agents' model and to include in it political establishment, tax payers and business.

The proposed model in Figure 6 is conceptual and does not contain feedback loops. 


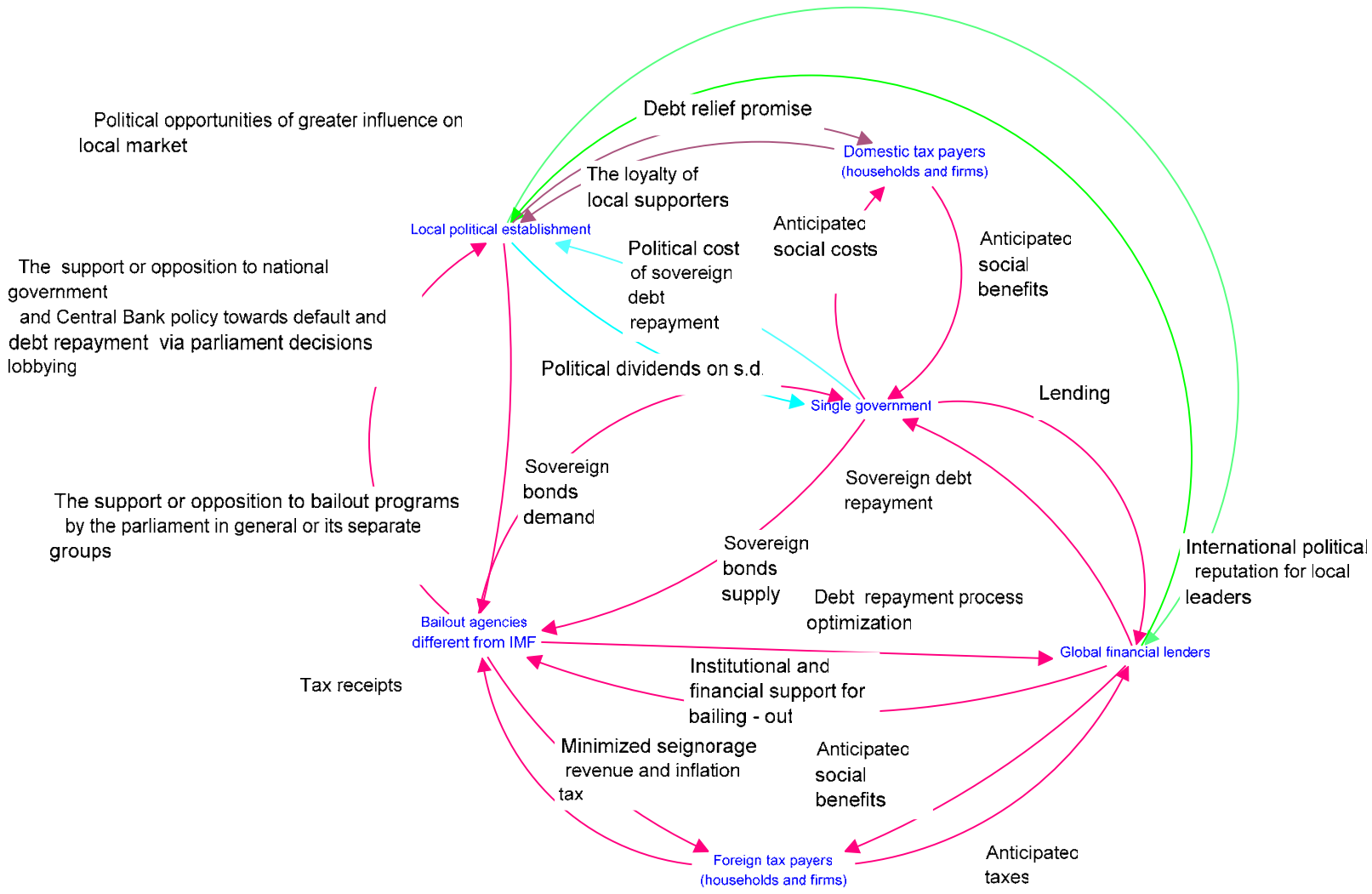

Fig. 6. The conceptual model of the sovereign debt game process (incl. major players) using the principle of tightly coupled dynamic complexity

The tightly coupled principle of system dynamics may be developed by the path dependence one. The agents (players) on sovereign debt market create the basic rules for economic process development and are the initial triggers for the ultimate state of economic system. History dependence is the one of the main components for debt resilience. It is closely connected with history dependence and is reflected on Figure 7.

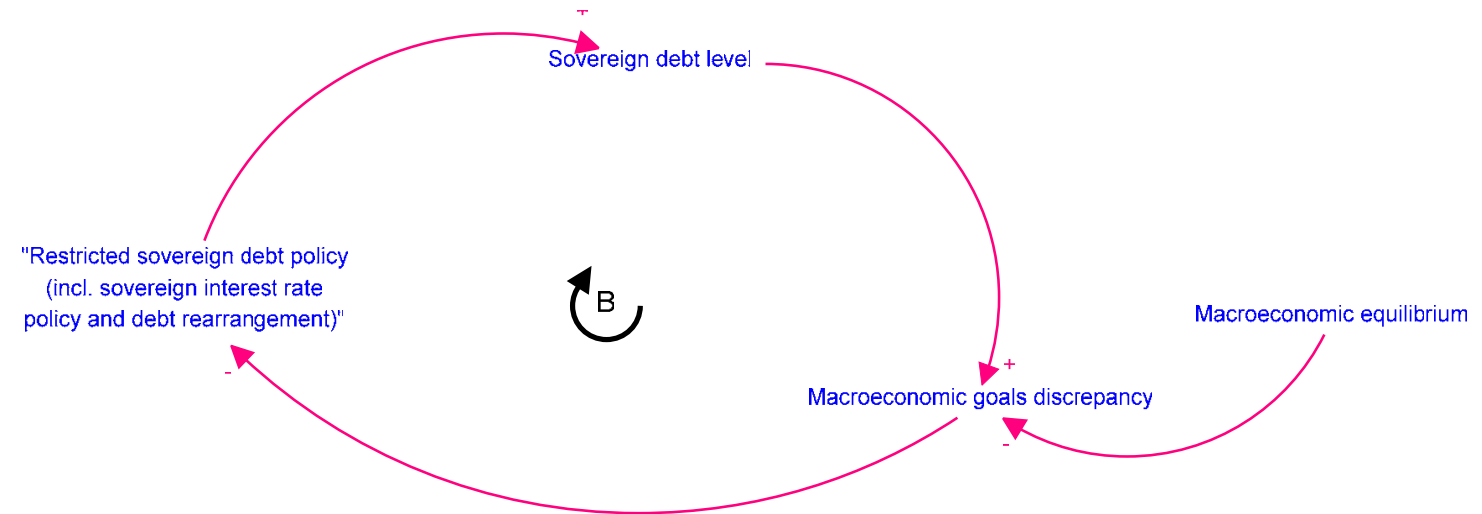

Fig. 7. Path dependence on sovereign debt market - locally stable equilibrium

There is a locally stable equilibrium, presented on Fig.7. The critical level of sovereign debt forces the economy to push it back towards more tough (restricted) internal fiscal or/and monetary policy which can turn the economy back to the status of completely debt-free.

The opposite to completely debt-free country is the situation of "bad debtor", presented on figure 8., which is more realistic. The first very first external credit push creates the "snowball" of bad loans, which is repelling the national economy from the point of initial debt - free equilibrium. The path - dependence is created by the increasing level of above - mentioned unpaid bad loans and is compounding by sovereign debt interest rate. The critical level of disequilibrium leads to sovereign default and significant downgrade of the economic status of national economy in global economy (for instance - from developing to underdeveloped one). 


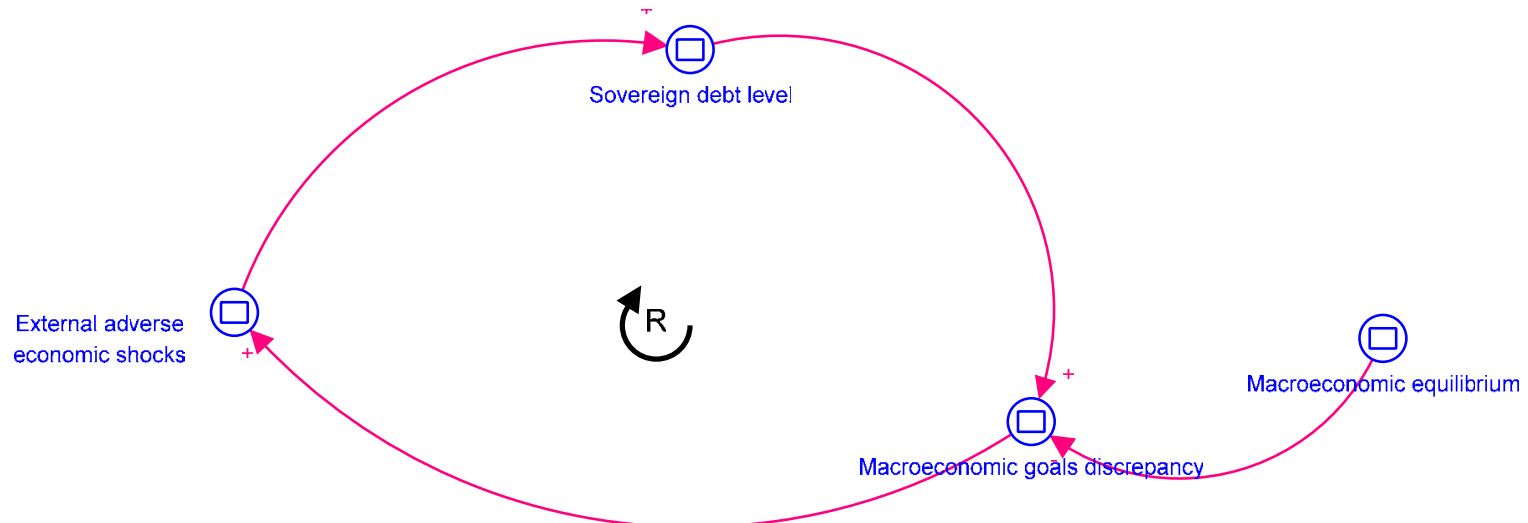

Fig. 8. Path dependence on sovereign debt market - locally unstable equilibrium

The Path dependence of sovereign debt can be also shortly described by the Polya process. If the economy has both the experience of sovereign default and its repayment, that is the stochastic process, because it is quite difficult to predict the non - linear development of social process. For instance, the IMF in March 2020 has warned about the possibility of default in a case of "Anti - Kolomoyski" law non- adaption. Despite of the above - mentioned law adaption, the resignation of the Head of National Bank of Ukraine in July 2020 increased the probability of sovereign default. "The resignation of Ukraine's Central Bank governor, Yakiv Smoliy, is unlikely to upend the country's IMF deal, but failure to replace him with a credible candidate or backsliding on recent key pieces of legislation would make this a major threat and risk Ukraine sliding towards sovereign default and a balance of payments crisis" [17].

The principle of sovereign debt application to Polya process is based on the idea that one sovereign debt occasion reinforces the chance of another one to be added to the "Polya urn". The above-mentioned process can be briefly described on Figure 9.

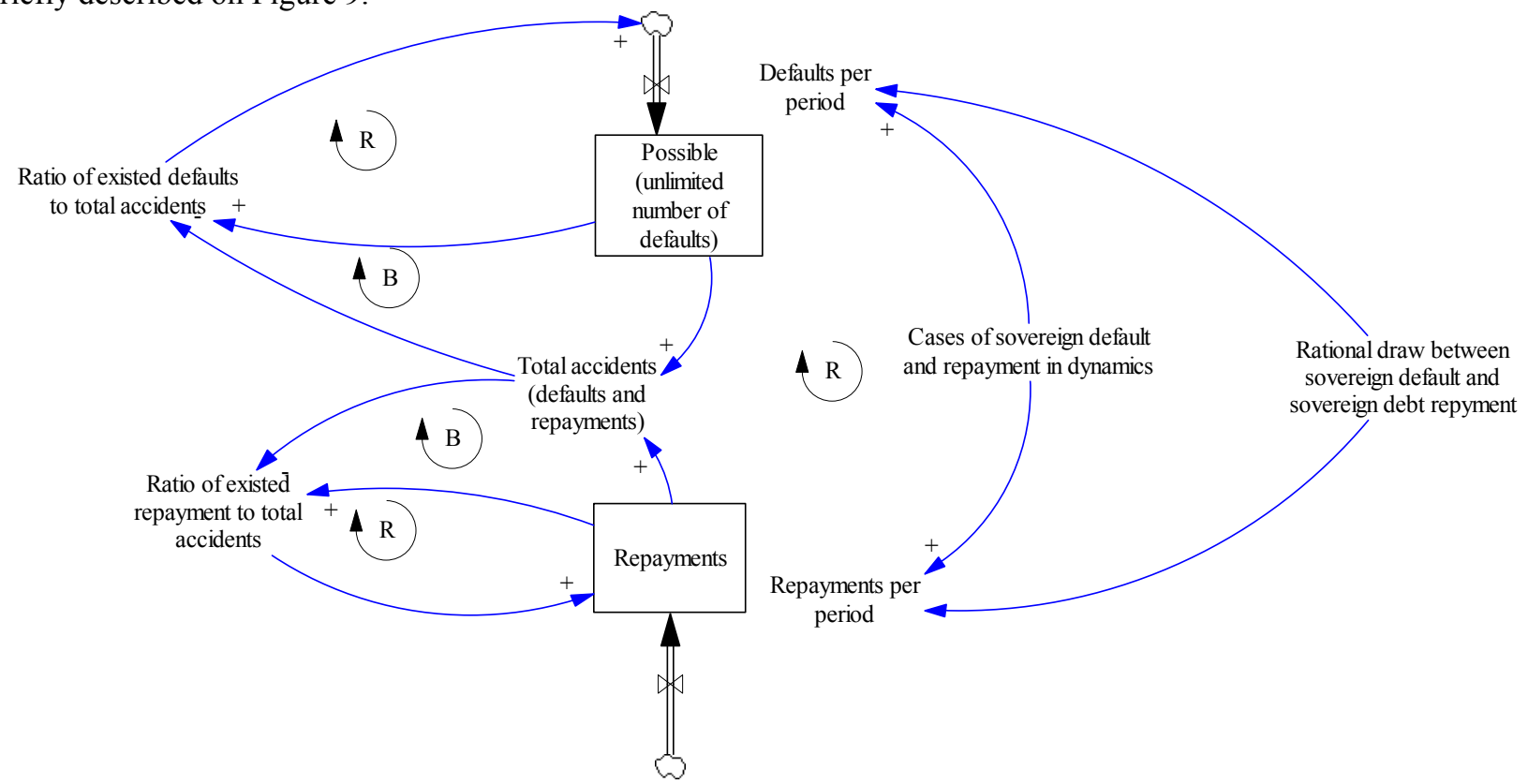

Fig. 9. The Polya process in sovereign default and repayment explanation [based on 16. p. 355, Figure 10 - 2 ]

There is the probability for repayment as well for sovereign default in national economy (Fig.9). The more times the sovereign default (s,d.) occurs, the higher is the probability for the next s.d. to happen, or path dependence to occur.. It means, that the positive trajectory of repayments in general exceeded the possibility of defaults. This case is being demonstrated on Figures 11 and 12. We used [11] as the simulator of the process, using the categories of "sovereign default" and "sovereign debt repayment" instead of "white balls" and "red balls".

The time (number of trials) is 29 and responds to the total sum of years since 1991, as the starting point of Ukrainian independence. As of July 2020, the Ukrainian economy had 3 sovereign defaults, or 3 years (1998, 2000, 2015) which are considered as sovereign default by international financial institutions and sovereign agencies, as well as global investors. 26 years may be considered as successful in sovereign debt repayment. There were 10 simulations of the Pola process with the length of 29 (responds to years) each. As the Figure 10 demonstrates, the system is unstable - the more is the number of trials, the more unpredictable the system is (greater fluctuations of the sovereign debt repayment towards sovereign default). The system does not lock in to possible balance. The same situation is on the Figure 11 - we are not observing the uniform distribution of the proportion of sovereign defaults. Positive feedback loops are overlapped by undetermined negative one, which is the aim of further research. 


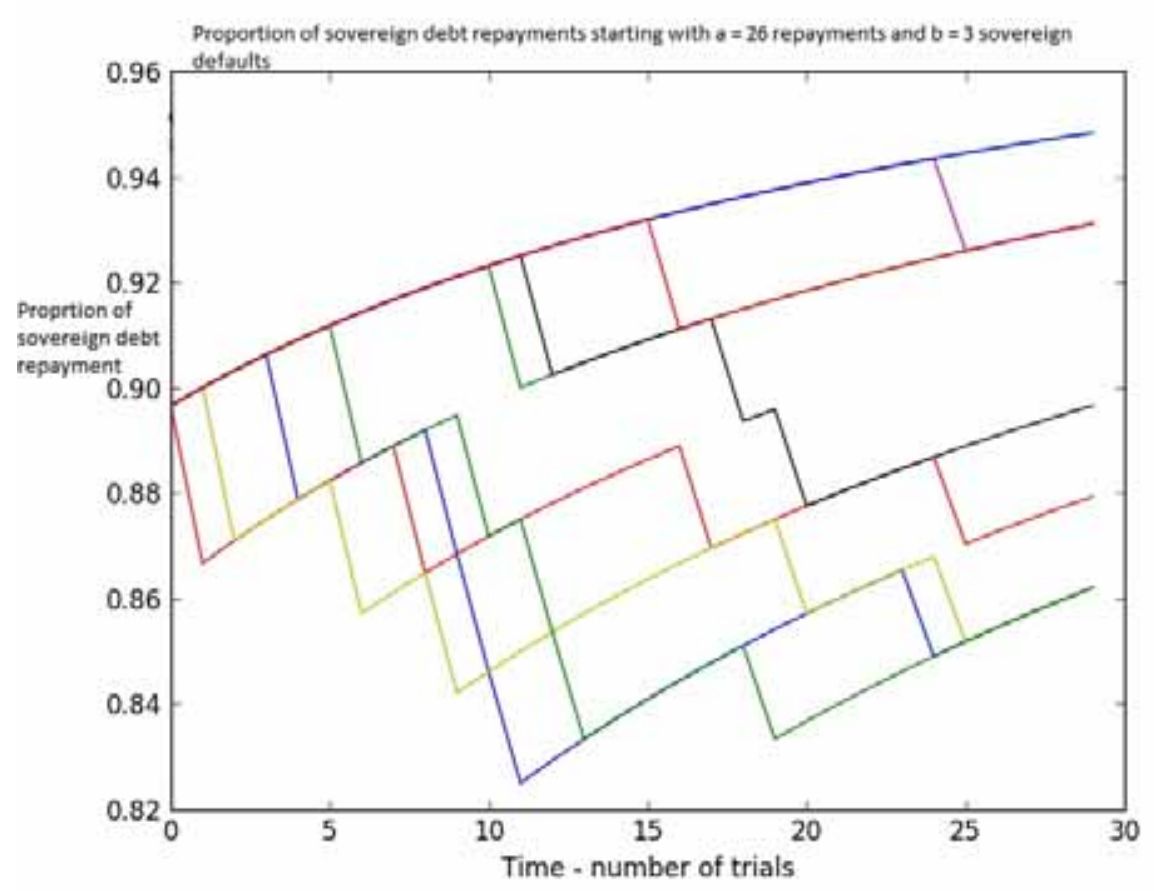

Fig. 10. Polya process demonstration in a case of the sovereign default versus debt repayment: calculations are based on [11]

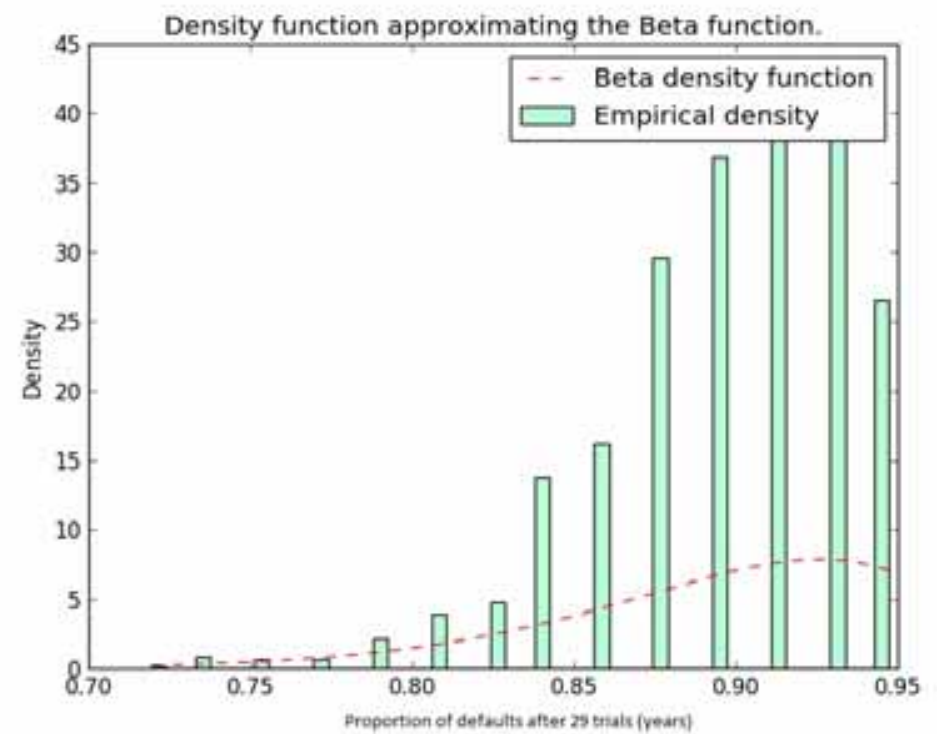

Fig. 11. Density function for sovereign default probability after 29 years (trials): calculations are based on [11]

\section{The findings of the study and the prospects for further researches}

We assume, that overcoming of the sovereign debt trap in a form of the mental model change is based on changing the structure of the existing relationship between economic agents (national and global) in the field of credit relationships. To overcome the history dependence of the "sovereign debtor nation" we need to create additional "reinforcing loops" in a form of stimulating foreign direct investment on the first stage of economic development and the gradual increase of the internal investment on the second stage. The inability to create the above mentioned additional "reinforcing loops" creates the affirmative answer for question raised in the title of the article:" sovereign debt resistance overcoming is a premise of sovereign default path dependence occurrence".

The major prospects of the research is in findings the additional factors, with nonlinear structure for determining path dependence of debt servicing using nonlinear Polya processes with further formulating the dynamic P'HAPI (Problem, Hypothesis,Analysis,Policy,Implemenation) model. 


\section{References.}

1. Cabinet of Ministers of Ukraine (2020), Resolution "On the establishment of the Public Debt Management Agency of Ukraine", available at: https://zakon.rada.gov.ua/laws/show/127-2020-\%D0\%BF\#Text

(Accessed 12 April 2020).

2. Amin, S. (1974), Accumulation on a world scale: a critique of the theory of underdevelopment (2 Volumes), Monthly Review Press, New-York, USA.

3. Argyris, C. and Schön, D. (1992), Theory in practice: Increasing professional effectiveness. JosseyBass Publishers, San Francisco, USA.

4. Blommestein, H. and Turner, P. (2012), "Interactions Between Sovereign Debt Management and Monetary Policy Under Fiscal Dominance and Financial Instability", OECD Working Papers on Sovereign Borrowing and Public Debt Management, [Online], no. 3, available at http://dx.doi.org/10.1787/5k9fdwrnd1g3-en (Accessed 20 February 2020).

5. Committee for a Responsible Federal Budget (2014), “CBO: Consequences of a Growing National Debt", available at:

http://www.crfb.org/blogs/cbo-consequences-growing-national-debt\# (Accessed 21 July 2020).

6. Eaton, J. and Gersovitz, M. (1981), "Debt with Potential Repudiation: Theoretical and Empirical Analysis", The Review of Economic Studies, vol. 48, no. 2, pp. 289-309.

7. Eichengreen, B. El-Ganainy, A. Esteves, R. and Mitchener, K. (2019) "Public debt through ages", VoxEU.org -CEPR's policy portal, [Online], available at: https://voxeu.org/article/public-debt-through-ages + (Accessed 01 April 2020).

8. Grabchuck, O. (2012), "Financial forecasting of Ukraine's external debt uncertainty", Visnyk Dnipropetrovs'koho universytetu. Seriia "Ekonomika", Vol 6, no.3, pp. 61 - 66, [Online], available at: http://www.vestnikdnu.com.ua/archive/201263/61-66.html (Accessed 01 July 2020).

9. Kahneman, D. (2003), "Maps of Bounded Rationality: Psychology for Behavioral Economics", American Economic Review, Vol 93, no.55, pp. 1449-1475.

10. Kruger, M. and Messmacher, M. (2004), "Sovereign debt defaults and financing needs", IMF working paper, [Online], WP 04/53, available at: https://www.imf.org/external/pubs/ft/wp/2004/wp0453.pdf (Accessed 07 April 2020).

11. Laboratoire de Probabilités, Statistique et Modélisation (2020), "Polya urn simulation", available at: http://simulations.lpsm.paris/polya/ (Accessed 02 July 2020).

12. Mesjasz, C. and Mesjasz, L, (2016), "Determinants of complexity of sovereign debt negotiation", Journal of economics and management, [Online], Vol 25, no.25. - pp. 63 - 78, available at: https://www.researchgate.net/publication/313258828_Determinants_of_Complexity_of_Sovereign_Debt_Negotiation (Accessed 15 July 2020).

13. Roch, F. and Uhlig, H. (2016), “The Dynamics of Sovereign Debt Crises and Bailouts”, International Monetary Fund Working Papers, [Online], Vol.16, no.136, available at: https://www.imf.org/external/pubs/ft/wp/2016/wp16136.pdf (Accessed 01 July 2020).

14. Smirnov, O. (2010), "Savings of the population in the context of anti-crisis policy", Naukovi pratsi Chornomors'koho derzhavnoho universytetu imeni Petra Mohyly kompleksu "Kyievo-Mohylians'ka akademiia", [Online], Vol. 126, no.113, pp. 11- 19, available at: at: http://nbuv.gov.ua/UJRN/Npchduec_2010_126_113_4 (Accessed 16 June 2020).

15. Sofienko, A. (2017), "Stages and features of the external government debt of Ukraine formation", Fynansovye usluhy, [Online], Vol 6., pp. 24 - 28, available at: http://nbuv.gov.ua/UJRN/finu 20176 8 (Accessed 15 April 2020).

16. Sterman, J. (2000), Business dynamics. System thinking and modelling for a complex world, Irwin McGraw - Hill, USA.

17. Tuvey, J. (2020), "Ukraine in the spotlight, Russia's sanctions treat. Emerging Europe economics weekly", Capital Economics, [Online], available at: https://www.capitaleconomics.com/publications/emerging-europeeconomics/emerging-europe-economics-weekly/ukraine-in-the-spotlight-russias-sanctions-threat/ (Accessed 14 April 2020).

18. The World Bank (2014), World Development Report 2015: Mind, Society, and Behavior, World Bank, Washington, DC, USA, [Online], available at:

https://www.worldbank.org/content/dam/Worldbank/Publications/WDR/WDR\%202015/WDR-2015-FullReport.pdf (Accessed 25 May 2020). 